\title{
BIODEGRADATION OF POLYETHYLENE BY BACTERIAL STRAINS ISOLATED FROM KASHMIR CAVE, BUNER, PAKISTAN
}

\author{
Syed Umair ullah Jamil ${ }^{1,2}$, Sahib Zada ${ }^{1}$, Imran $\operatorname{Khan}^{1}{ }^{1}$, Wasim Sajuad ${ }^{1}$, Muhammad Rafiq ${ }^{1}$, Aamer Ali \\ $\mathrm{SHAH}^{1}$, FARIHA HASAN $^{1 *}$
}

\begin{abstract}
Low density polyethylene (LDPE) is used for making common shopping bags and plastic sheets and is a significant source of environmental pollution. The present study was aimed at testing the ability of bacterial strains identified as Serratia sp. KC1-MRL, Bacillus licheniformis KC2-MRL, Bacillus sp. KC3-MRL and Stenotrophomonas sp. KC4MRL isolated from a limestone cave to degrade polyethylene. These strains were isolated from soil of Kashmir Smast, a limestone cave in Buner, Pakistan. These strains showed antibacterial activity against Micrococcus luteus, Klebsiella sp., Pseudomonas sp., and Staphylococcus aureus. The pieces of LDPE plastic were incubated along with bacterial strains for a period of one month and then analyzed. Degradation was observed in terms of growth of microorganisms used in consortia, chemical changes in the composition of LDPE by fourier-transform infrared spectroscopy, and changes in physical structure of LDPE by scanning electron microscopy. Maximum growth $\left(107 \times 10^{5} \mathrm{CFU} \mathrm{mL} \mathrm{mL}^{-1}\right)$ at $28{ }^{\circ} \mathrm{C}$ and subsequent change in chemical and physical properties of plastic were observed in the presence of calcium and glucose. The cave soil sample had a very high concentration of calcium. The microscopy showed adherence of bacteria with lots of mechanical damage and erosion on the surface of plastic films incubated with bacterial consortia. The spectroscopy showed breakdown and formation of many compounds, as evident by the appearance and disappearance of peaks in LDPE treated with bacterial consortia as compared to the untreated control. We conclude that antibiotic-producing cave bacteria were able to bring about physical and chemical changes in LDPE pieces and degradation of LDPE was enhanced in media augmented with calcium.
\end{abstract}

\section{INTRODUCTION}

Plastics are polymers of carbon, oxygen, and hydrogen and that are synthetically derived from petrochemicals and suitable for a wide range of usage. Since plastics are artificially manufactured, they are xenobiotic compounds and they resist degradation (Kawai, 2010).

Polyethylene is one of the most commonly used commercial plastics, found in various products ranging from simple plastic bags to artificial limbs (Orhan and Büyükgüngör, 2000; Shimao, 2001). Thermal and mechanical stability and their morphologies make polymeric substances one of the most popular commodity of the modern world (Rivard et al., 1995). Plastic waste is an environmental hazard. Plastic debris poses a direct threat to wildlife. The main dangers associated with plastic objects for most species are related to entanglement and ingestion. Juvenile animals, in particular, often become entangled in plastic debris, which can result in serious injury as the animal grows, not to mention restriction of movement, preventing animals from properly feeding and, in the case of mammals, breathing (Webb et al., 2012). Due to plastic's resilience against degradation and its proliferation in industry, the issue of plastic pollution has evolved to become a threat to global ecology.
Management of plastic waste is an ever-increasing problem, and none of the current techniques of solid waste management completely alleviate all the concerns related to these recalcitrant polymers (Nkwachukwu et al., 2013). One way to deal with these polymers could be to alter the manufacturing process, and new formulations should be developed with special considerations on mechanism for their biodegradation. These alterations could include looking into factors that can aid in biodegradation like $\mathrm{pH}$, temperature, chemical structure, polymeric morphology, presence or absence of certain additives, and most importantly, the type of organisms that can be involved ( $\mathrm{Gu}$ and $\mathrm{Gu}, 2005$ ).

Degradation of plastics is carried out by organisms that are chemoheterotrophs. Many studies have shown the presence of such bacteria in caves. Bacteria also have the ability to utilize hydrocarbons as a source of energy. Studies have shown that a variety of culturable chemoheterotrophs are present in microhabitats of caves and catacombs (De Leo et al., 2012). The microorganisms living under stressful or low nutrient habitats

\footnotetext{
* Corresponding Author: farihahasan@yahoo.com

${ }^{1}$ Department of Microbiology, Quaid-i-Azam University, Islamabad, 45320. Pakistan.

${ }^{2}$ Department of Earth and Environmental Sciences, Bahria University, Islamabad, Pakistan.
} 
can develop the ability to use any available nutrient to survive. Studies on a bacterial strain belonging to the Arthrobacter genus from alpine ice showed biodegradation of phenol under various environmental conditions (Margesin et al., 2004). Bacteria present in caves are capable of carrying out a variety of biodegradative and biodeteriorative processes. Extensive studies have reported biodeteriorative effects of microorganisms in cave environment (Cuezva et al., 2012; SchabereiterGurtner et al., 2002).

Despite much study, the knowledge is very limited about microbial life in diverse and extreme habitats like caves. There exists much potential for isolating and studying microbes in caves that have unique and unexplored characteristics of potential commercial applicability. These studies can also be helpful in investigating evolutionary relationships of microorganisms in cave environment. Most caves are characterized as having very low nutrient availability, constant low temperature, and high humidity. Caves can either be terrestrial or aquatic. Some may be rich in specific natural minerals or have exposure to nutrient sources, and therefore, different caves will have different types of microorganisms inhabiting various ecological niches (Zada et al., 2016). Fauna, environmental factors, temperature, humidity, organic matter, and other environmental factors influence activities such as nutrient cycling, and geomicrobiological activities including the formation or alteration of cave structures (Adetutu and Ball, 2014). Cave organisms have evolved some extraordinary abilities to survive and live in this inhospitable environment.

Polyethylene makes a significant contribution to solid waste in developed countries. Management of this waste can be carried out by chemical, physical, and biological methods. Various natural microflora of soil, including bacteria and fungi, are reported to degrade low-density polyethylene (LDPE) under various physical and chemical environments. This study determines the degradation capacity of four bacterial strains isolated from Kashmir Smast, Khyber Pakhtoon Khwa, Pakistan. The bacteria isolated were previously identified and tested positive for antibiotic production in the Microbiology Research Laboratory (MRL), Department of Microbiology, Quaid-e-Azam University, Islamabad. Since antibiotic production and LDPE degradation takes place under stressed environmental conditions, it was hypothesized that bacteria positive for the first character may also be positive for the other character. For this purpose, commercially available LDPE from a shopping bag was used. Bacterial isolates Serratia sp. KC1-MRL, Bacillus licheniformis KC2-MRL, Bacillus sp. KC3-MRL, and Stenotrophomonas sp. KC4-MRL were used in consortia. The study was carried out in six different medium compositions or modifications, and their individual effects were analyzed by determining total viable cells, fourier-transform infrared spectroscopy, and scanning electron microscopy. Isolated bacteria were inoculated in mineral salt medium, and sterilized LDPE pieces were added in the flasks.

\section{Materials AND Methods}

\section{Sampling Site and Sample Collection}

Soil samples were collected from Kashmir Smast (cave), Nanser, Buner, Khyber Pakhtunkhwa (Fig. 1). The Kashmir Smast is a series of natural limestone caves probably of marine origin (Khan, 2013). These caves are located in the Babozai Mountains between Mardan and Buner in northern Pakistan. The only source of water was drip water. Two soil samples were collected from wall and ground surfaces of the cave in sterile Falcon tubes under aseptic conditions. Samples were collected from the dark end of the cave about $188 \mathrm{~m}$ from the entrance. This cave is located far away from human access, so human intervention is negligible (Zada et al., 2016). The samples were then brought to the laboratory in an icebox and stored at $4{ }^{\circ} \mathrm{C}$ for further processing. The $\mathrm{pH}$ and temperature of soil was recorded as 7.2 and $25{ }^{\circ} \mathrm{C}$.

\section{Soll Analysis by Atomic Absorption}

For the quantitative analysis of elements in the soil sample, atomic-absorption spectrophotometry was performed with a AA240FS Fast Sequential Atomic Absorption Spectrophotometer. Soil digestion was performed to prepare samples for analysis. One gram each of soil from the cave floor and control soil from outside the cave were ground separately and were then mixed in $15 \mathrm{~mL}$ aqua regia, heated at $15^{\circ} \mathrm{C}$, and left overnight. Then $5 \mathrm{~mL}$ of $\mathrm{HClO}_{4}$ was added and again heated at $150{ }^{\circ} \mathrm{C}$. The solution almost became dry before brown fumes were produced. Whatman filter paper (No. 42) was used for filtration, and the volume was made up to $50 \mathrm{~mL}$ using double-distilled water (Kelly et al., 2008).

\section{SCREENING AND IsOlation OF LDPE-DEgRADING BACTERIA}

Previously identified strains of Serratia sp. KC1-MRL, Bacillus licheniformis KC2-MRL, Bacillus sp. KC3-MRL, and Stenotrophomonas sp. KCMRL isolated from the cave were used in consortium to carry out biodegradation of polyethylene. Nutrient agar medium was used for isolation of bacterial strains from cave soil. The strains were isolated using standard serial dilution methods and subsequent growth on Nutrient agar plates for $48 \mathrm{~h}$ at $37{ }^{\circ} \mathrm{C}$. All the isolated strains were screened for polyethylene degradation. For this purpose the strains were incubated for two weeks in $120 \mathrm{~mL}$ of mineral salt medium $\left(\mathrm{g} \mathrm{L}^{-1}\right)$ : $\left[\mathrm{KH}_{2} \mathrm{PO}_{4}, 2.0\right.$; $\mathrm{K}_{2} \mathrm{HPO}_{4}, 7.0 ; \mathrm{MgSO}_{4} \cdot 7 \mathrm{H}_{2} \mathrm{O}, 0.1 ; \mathrm{ZnSO}_{4} \cdot 7 \mathrm{H}_{2} \mathrm{O}, 0.001$; $\mathrm{FeSO}_{4} \cdot 7 \mathrm{H}_{2} \mathrm{O}, 0.01 ; \mathrm{MnSO}_{4} \cdot 6 \mathrm{H}_{2} \mathrm{O}, 0.002 ; \mathrm{NH}_{4} \mathrm{NO}_{3}, 1.0$; $\left.\mathrm{CuSO}_{4} \cdot 7 \mathrm{H}_{2} \mathrm{O}, 0.0001 ; \mathrm{pH} 7.2\right]$ at $37{ }^{\circ} \mathrm{C}$ with pieces of polyethylene (1 by $1 \mathrm{~cm}$ ) (Anwar et al., 2009). Polyethylene used was pretreated by exposing it to UV light for three minutes. At the end of two weeks of incubation, viable cells were counted as CFU mL $\mathrm{mL}^{-1}$ by serial dilution. Four bacterial strains were found active in terms of growth in the medium. 


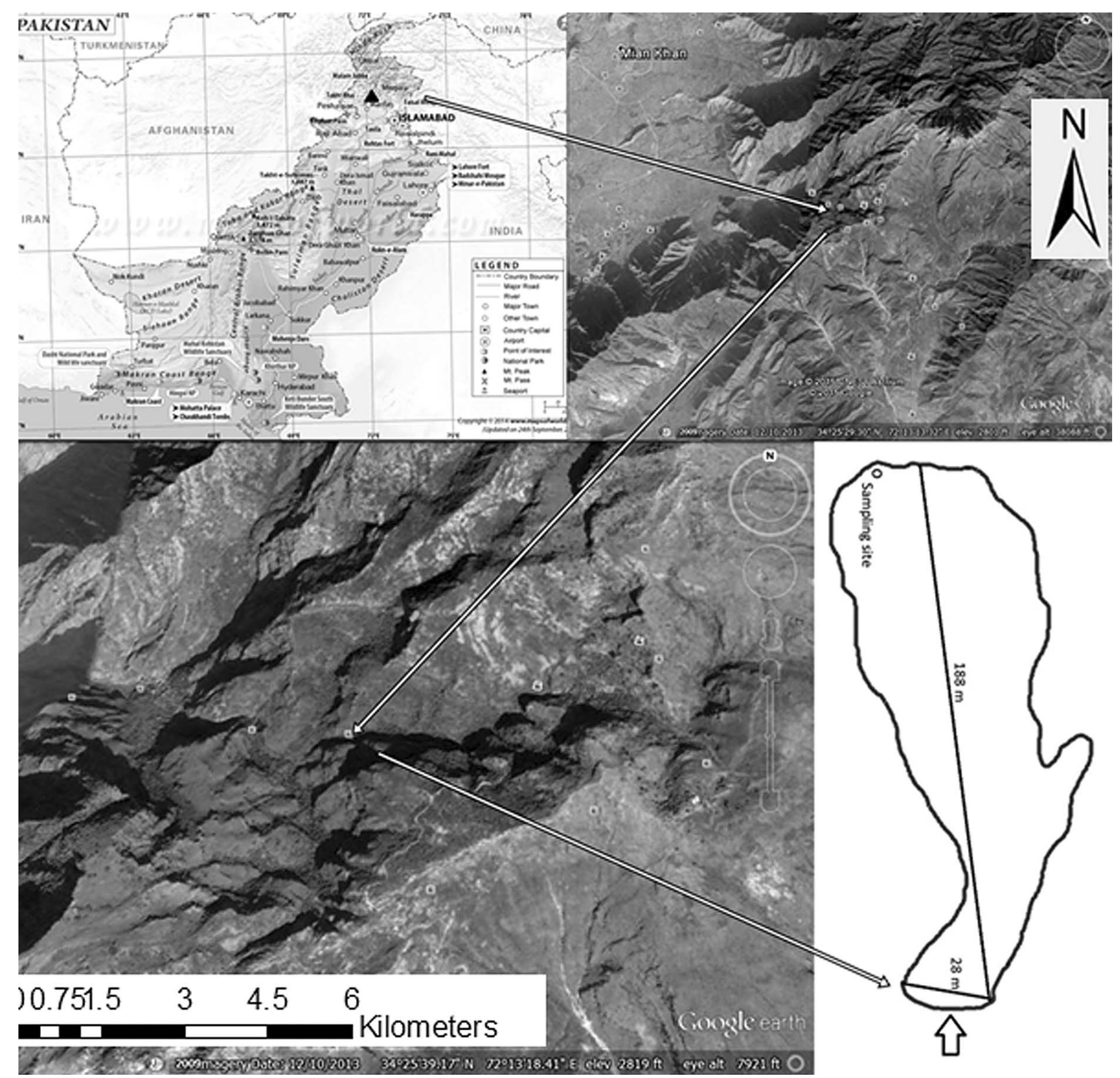

Figure 1. Location and map of Kashmir Smast (Cave), Nanseer Buner, Khyber Pakhtunkhwa, Pakistan. Sourc Zada et al. (2016).

Bacterial colonies were further purified and enriched on nutrient agar plates.

\section{Preparation OF INOCULUM}

About $10 \mathrm{~mL}$ of nutrient broth was inoculated with two or three loops of the pure culture of isolated strains. Bacterial growth was evaluated at $25^{\circ} \mathrm{C}, 37{ }^{\circ} \mathrm{C}$ and $40{ }^{\circ} \mathrm{C}$. Maximum growth was observed at $37{ }^{\circ} \mathrm{C}$ (O.D. at $\left.600 \mathrm{~nm}\right)$. Consortia were developed by taking inocula from each test tube into a separate flask with $100 \mathrm{ml}$ of nutrient broth. Five percent of this prepared consortia was used as inoculum for further biodegradation experiments.

\section{Medium Preparation and Incubation}

Different metabolites were used in combinations to study their effects on biodegradation of polyethylene by the cavebacteria consortia. Glucose, yeast extract, and calcium were used as co- metabolites. About $1 \% \mathrm{w} / \mathrm{v}$ of glucose and yeast extract were used, whereas the concentration of calcium in the medium was maintained at $0.03 \%$ to match the natural concentration of calcium of the environment where the soil was taken.

In total six combinations of these metabolites in mineral salt medium with polyethylene pieces and bacterial consortia were incubated at $150 \mathrm{rpm}$ at $\mathrm{pH} 7.2$ and temperature $37{ }^{\circ} \mathrm{C}$ 


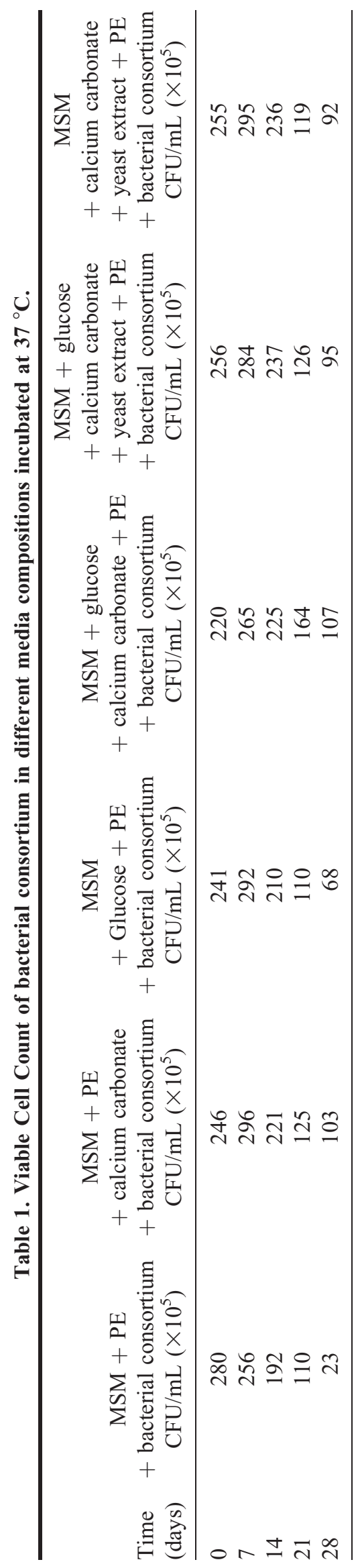

for four weeks. A negative control was set by incubating polyethylene pieces in mineral salt medium with no bacterial inoculum.

\section{Biodegradation AnALysis}

Biodegradation of polyethylene was analyzed by determining CFU $\mathrm{mL}^{-1}$, fourier-transform infrared spectra, and scanning electron microscope images. $\mathrm{CFU} \mathrm{mL}^{-1}$ was determined after every week, whereas FTIR and SEM analysis were performed after one month of incubation. The viable cell count was done for bacterial growth determination through serial dilution and calculating CFU mL $\mathrm{mL}^{-1}$. Test LDPE samples were compared with the untreated control samples. FTIR (Jasco FT/ IR - 620) analysis was performed to check the degradation of LDPE pieces after being mixed with the growing bacterial consortia in liquid medium. This analysis detects any change in the functional groups. Spectrum was recorded at 500-4000 wave-numbers $\mathrm{cm}^{-1}$ for all the LDPE samples. Surface morphology of LDPE pieces was observed by SEM (JSM 5910 Joel, Japan) to look for any change in structure or surface of LDPE piece after treating with microbial consortia. After rinsing of the LDPE pieces with autoclaved distilled water, LDPE pieces were mounted on the copper stubs with gold paint. Gold coating was carried out under vacuum by evaporation to make the samples conducting.

\section{RESULTS}

\section{SoIl AnAlysis}

Atomic absorption spectroscopy was performed to determine the concentration of elements in the cave soil sample (ZADA et al., 2016). Ca was $332.938 \mathrm{mg} \mathrm{kg}^{-1}$ as compared to $121.65 \mathrm{mg} \mathrm{kg}^{-1}$ in control soil, $\mathrm{Mg}$ was $1.2576 \mathrm{mg} \mathrm{kg}^{-1}$ in cave soil and $1.023 \mathrm{mg} \mathrm{kg}^{-1}$ in control soil. Ni $0.965 \mathrm{mg} \mathrm{kg}^{-1}$ in cave soil and $10.4 \mathrm{mg} \mathrm{kg}^{-1}$ in control soil, $\mathrm{Cr} 0.571 \mathrm{mg} \mathrm{kg}^{-1}$ in cave soil and $8.74 \mathrm{mg} \mathrm{kg}^{-1}$ in control soil, Co $0.266 \mathrm{mg} \mathrm{kg}^{-1}$ in cave soil and $0.810 \mathrm{mg} \mathrm{kg}^{-1}$ in control soil, $\mathrm{Cu} 1.824 \mathrm{mg}$ $\mathrm{kg}^{-1}$ in cave soil and $4.7 \mathrm{mg} \mathrm{kg}^{-1}$ in control soil, $\mathrm{Zn} 12.7311$ $\mathrm{mg} \mathrm{kg}^{-1}$ in cave soil and $36.41 \mathrm{mg} \mathrm{kg}^{-1}$ in control soil, and $\mathrm{Pb}$ $1.31 \mathrm{mg} \mathrm{kg}^{-1}$ in cave soil and $8.14 \mathrm{mg} \mathrm{kg}^{-1}$ in control soil were much lower than those found in the control soil (Zada et al., 2016).

\section{Viable Cell Count}

The concentration of viable cells in $\mathrm{CFU} \mathrm{mL}^{-1}$ was determined at time zero, before initial incubation, and then after every week for a period of one month (Table 1). Since polyethylene in the medium was the sole carbon source, $\mathrm{CFU}$ $\mathrm{mL}^{-1}$ is directly proportional to the ability of organisms to degrade polyethylene and use it as a carbon source. There was a consistent decrease in CFU mL $\mathrm{mL}^{-1}$ after three and four weeks of incubation. The soil from where the bacteria were isolated contained exceptionally high concentration of calcium. Considering this high amount of calcium in the native habitat 

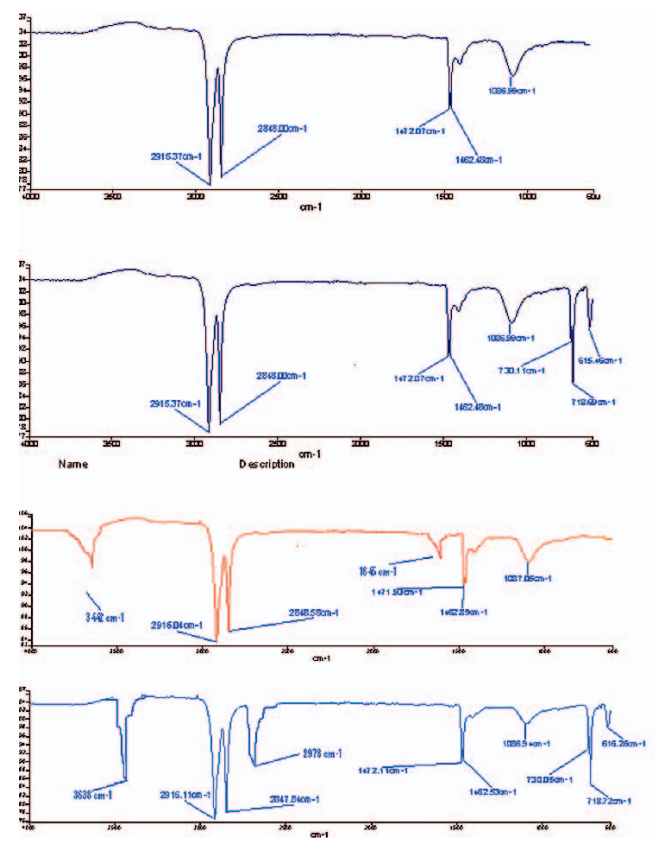

A: Control (untreated) sample
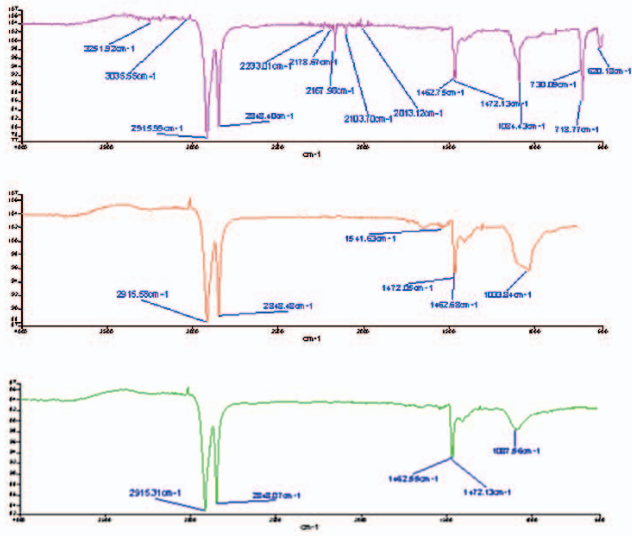

B: No additives

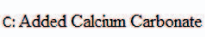

E: Added Calcium Carbonate

and Glucose Glucose and Yeast extract

D: Added Glucose

Figure 2. Fourier-transform infrared spectra from control and different media after incubation at $37{ }^{\circ} \mathrm{C}$ for one month.

of the organism, extra calcium salt was added in the medium so that the organisms experience minimum deviation from their natural environment. Medium augmented with extra calcium showed increasing values of viable cell count in the first two weeks of incubation. Increase in the values of viable cell count was also observed in the first two weeks of incubation when the medium is augmented with glucose; these higher values of CFU mL $\mathrm{mL}^{-1}$ in first two weeks were because the bacteria were provided with glucose that acted as growth activator. Additional amounts of calcium proved to be helpful for better growth of bacterial colonies.

\section{Fourier Transform Infra-Red Spectroscopy}

FTIR was carried out on LDPE films after incubation with bacterial consortia for four weeks. The peaks formed were compared with the control (Fig. 2).

LDPE in mineral salt medium containing bacterial consortia: Absorbance peaks formed at $2915 \mathrm{~cm}^{-1}$ and 2848 $\mathrm{cm}^{-1}$ suggest presence of $\mathrm{C}-\mathrm{H}$ bonds. A peak of variable strength at $1472 \mathrm{~cm}^{-1}$ and $1462 \mathrm{~cm}^{-1}$ shows formation of $\mathrm{C}=\mathrm{C}$ bonds. A strong peak at $1035 \mathrm{~cm}^{-1}$ shows formation of stretch of $\mathrm{C}-\mathrm{O}$ bonds. Absorbance peaks formed at $615 \mathrm{~cm}^{-1}, 718$ $\mathrm{cm}^{-1}$ and $730 \mathrm{~cm}^{-1}$ show presence of $=\mathrm{C}-\mathrm{H}$ bending bonds.

LDPE in MSM containing calcium carbonate and bacterial consortia: New peaks were formed at $1645 \mathrm{~cm}^{-1}$ that represent formation of $\mathrm{C}=\mathrm{C}$, and a peak formed at $3442 \mathrm{~cm}^{-1}$ shows stretching of $\mathrm{O}-\mathrm{H}$ bonds.

LDPE in MSM containing glucose and bacterial consortia: Formation of new peak at $2978 \mathrm{~cm}^{-1}$ shows stretching of $\mathrm{C}-\mathrm{H}$ bonds and peak at $3638 \mathrm{~cm}^{-1}$ represents of stretching of $\mathrm{O}-\mathrm{H}$ bonds.
LDPE in MSM containing calcium carbonate, glucose, and bacterial consortia: Maximum variety of peaks was observed in this film. Formation of peaks at $3251 \mathrm{~cm}^{-1}$ and $3032 \mathrm{~cm}^{-1}$ shows formation of $\mathrm{O}-\mathrm{H}$ bonds. A peak at 2915 $\mathrm{cm}^{-1}$ and $2848 \mathrm{~cm}^{-1}$ represents formation of stretch of $\mathrm{C}-\mathrm{H}$ bonds in the polyethylene. Peak formation at $2233 \mathrm{~cm}^{-1}$, $2178 \mathrm{~cm}^{-1}, 2167 \mathrm{~cm}^{-1}, 2103 \mathrm{~cm}^{-1}$, and $2013 \mathrm{~cm}^{-1}$ shows that new Nitrile bonds of $-\mathrm{C} \equiv \mathrm{N}$ are formed. Absorbance peaks at $1462 \mathrm{~cm}^{-1}$ and $1472 \mathrm{~cm}^{-1}$ show bending of $-\mathrm{C}-\mathrm{H}-$ bonds. Peak at $1084 \mathrm{~cm}^{-1}$ shows formation of stretch of $\mathrm{C}-\mathrm{O}$ functional group. Absorbance peaks formed at $615 \mathrm{~cm}^{-1}$, $718 \mathrm{~cm}^{-1}$, and $730 \mathrm{~cm}^{-1}$ shows presence of $=\mathrm{C}-\mathrm{H}$ bending bonds.

LDPE in MSM containing calcium carbonate, glucose, yeast extract, and bacterial consortia: In comparison with control, new peak was formed in this medium combination at $1033 \mathrm{~cm}^{-1}$ represents formation of $\mathrm{C}-\mathrm{O}$ bond.

LDPE in MSM containing calcium carbonate, yeast extract and bacterial consortia: In comparison with control, anew peak was formed in this medium combination at $1033 \mathrm{~cm}^{-1}$ that represents formation of $\mathrm{C}-\mathrm{O}$ bond.

\section{Scanning Electron Microscopy}

SEM showed adherence of bacteria that caused mechanical damage and erosion on the surface of plastic films incubated with bacterial consortia as compared to the untreated control (Fig. 3). More changes in surface topology and attachment of cells, despite the washing, were observed on the LDPE piece incubated in the presence of glucose and calcium. 

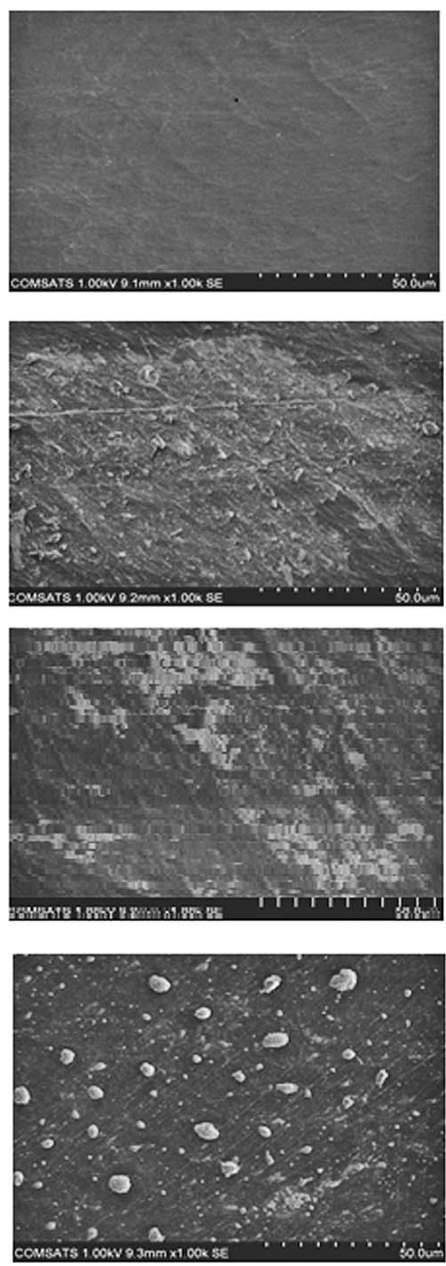

A: Control (untreated) sample

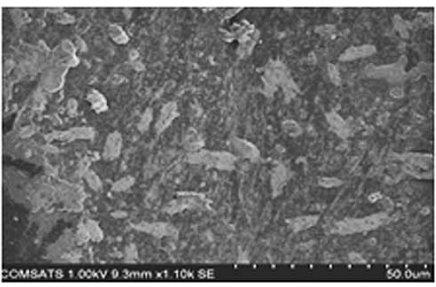

B: No additives

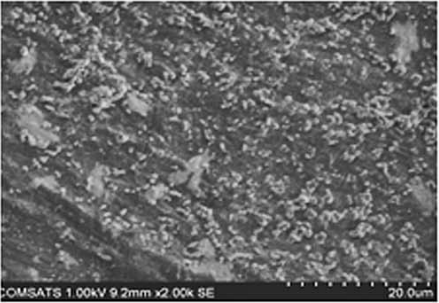

C: Added Calcium Carbonate

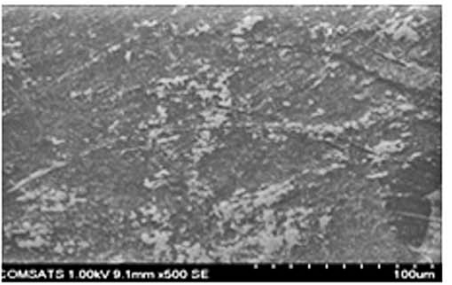

E: Added Calcium Carbonate and Glucose

\section{F: Added Calcium Carbonate,} Glucose and Yeast extract

\author{
G: Added Calcium Carbonate \\ and Yeast extract
}

Figure. 3 A-G. Scanning electron microscopy of low-density polyethylene samples under specified treatment after incubation with bacterial consortia at $37^{\circ} \mathrm{C}$ for one month.

\section{DisCUSSION}

There is an increasing interest in investigating biodegradation of non-degradable plastics using efficient microorganisms (Bonhomme et al., 2003; Boonchan et al., 2000; Lee et al., 1991). In our present study, bacterial isolates were obtained from the soil of Kashmir Smast, which is a limestone cave in Khyber Pakhtoonkhuwa province, Pakistan. The four isolates were identified as Serratia sp. KC1-MRL, Bacillus licheniformis KC2-MRL, Bacillus sp. KC3-MRL, and Stenotrophomonas sp. KC4-MRL. These strains were used in consortia to check for the ability of these microbes to degrade polyethylene. Since both antibiotic production and polyethylene degradation occur under stressed environmental conditions, the hypothesis of the current study was that bacteria having the first property are more likely to give positive result for the other. Studies on Brevibacillus borstelensis 707 showed an increase in potential of polyethylene biodegradation when grown on nitrogen-limit stressed cultures (Hadad et al., 2005). It was also observed that not only nitrogen deprivation, based on the amount of $\mathrm{KNO}_{3}$ in medium, but also carbon limitation in a mannitol-free medium alone enhanced degradation, which was also enhanced when used in combination. It was observed that mannitol-free medium supplemented with nitrogen source showed maximum biodegradation in 30 days of incubation. In the present study, it was found that bacterial consortia showed higher viable cells measured as $\mathrm{CFU} \mathrm{mL} \mathrm{mL}^{-1}$ when the medium was supplemented with the nitrogen source.

Loss of tensile strength of plastic after incubation with Pseudomonas stutzeri suggests that the bacterium is capable of degrading the polymer (Sharma and Sharma, 2004). When bacteria are grown in different media compositions along with a polymer, maximum turbidity is observed on forty-fifth day (Ciferri, 1999). The increase in growth rate in glucose, as well as in minimal medium, suggests that the bacteria were completely depending upon polyethylene film for its source of carbon in the absence of glucose. CFU mL $\mathrm{mL}^{-1}$ increased from $10^{1}$ to $10^{3}$ from day 15 to day 30 (Table 1 ). These results suggest that the bacteria growing in Lascaux Cave, France are 
capable of using plastics and other resins such as glue as their sole source of carbon. Higher values of CFU mL ${ }^{-1}$ in the first two weeks were observed in all those media combinations in which $1 \%$ glucose $\mathrm{w} / \mathrm{v}$ was added at the beginning. When the nutrients depleted, bacteria had polyethylene as the only carbon source. Addition of easily available substrate like glucose in MSM medium increases bacterial growth in initial stages of pesticide degradation (Cycoń et al., 2011). A similar effect on growth was observed when MSM media is augmented with yeast extract. The increased $\mathrm{CFU} \mathrm{mL} \mathrm{mL}^{-1}$ was observed in first two weeks of the experiment and then the growth decreased, which indicates depletion of glucose in the medium.

In our study, fourier-transform infrared spectral analysis was carried out to check chemical degradation of polyethylene. Low- and high-density polyethylene are made of the elements carbon and hydrogen forming chains of repeating $\mathrm{CH}_{2}$ - units (Rajandas et al., 2012). In the process of biodegradation of LDPE, enzymes catalyze a specific series of biochemical reactions that lead to various kinds of chemical conversions, such as oxidation, reduction, hydrolysis, esterification, and molecular inner conversion (Harshvardhan and Jha, 2013). Keto and ester carbonyls have been reported as major products in the presence of oxidoreductase (Karlsson and Albertsson, 1998). Analysis of FTIR showed new peaks when LDPE is treated with bacterial consortia, indicating polymer breakdown and formation of new functional groups. The results of scanning electron microscopy have shown that all those media to which calcium was added showed strong biofilm development and hence increased biodegradation. It is also evident in several studies that bacteria release various surface-active substances extracellularly, which increase the bioavailability to the polymer. Studies on Pseudomonas sp. AKS2 showed that the strain was capable of degradation $5 \pm$ $1 \%$ of initial LDPE in 45 days (Tribedi and Sil, 2013). The degradation by Pseudomonas depends on its capability to colonize the surface of the polymer and degrade it. Addition of calcium increases biofilm development of Xylella fastidiosa under in vitro conditions (Cruz et al., 2012). The efficient increase in formation of biofilm was observed when at least $1.0 \mathrm{mM} \mathrm{CaCl}_{2}$ was added in the medium. There was no effect of $\mathrm{Ca}$ on attachment when bacteria were treated with tetracycline, indicating that $\mathrm{Ca}$ has a regulatory role in colonization or attachment of the cells. In another study, Ehret and Böl (2013) showed that $\mathrm{Ca}$ ions crosslink alginates, which is the key constituent of the extracellular polymeric material produced by the mucoid $P$. aeruginosa strain to produce biofilms. Ciferri reported a list of bacteria responsible for degradation of paints (Ciferri, 1999).

In the present study, SEM showed discoloration, spots, erosion, and cracking on the surface of polyethylene film. Modification on the surface of polyethylene after bacterial treatment was also reported by (Matsunaga and Whitney, 2000). Formation of pits and erosion on the surface of LDPE when observed through electron microscopy when incubated with Fusarium sp. indicating adherence and degradation of LDPE (Hasan et al., 2007).

Bacteria capable of adhering to plastic surfaces, growing, and possibly degrading it by oxidation are commonly present in soil. Microorganisms that can adhere to the surface of preoxidized PE are also commonly present in soil. If the preoxidant technology is commonly employed in the PE manufacturing process, one can expect that these plastics will be able to degrade in waste disposal sites. In the current study, structural and surface changes in PE in the form of depression, pits, and erosions were visible in SEM. Physical erosion of the surface of polyethylene observed through SEM by fungi has been reported by Bonhomme et al. (2003). Polymer treated with microorganism loses its physical strength and disintegrates on applying mild pressure. Wide spread pits and holes in polycaprolactone surface are reported by Shaw et al. (2015) after ten days of incubation with thermophilic bacterium Ralstonia sp. strain MRL-TL. SEM has shown that biofilms develop on the surface of polyethylene with time by PEdegrading bacteria. It is known that formation of biofilm on the surface of plastics favors adhesion of bacteria on the surface and helps them survive under low nutrient conditions and to use polyethylene as their source of carbon (Linos et al., 2000).

\section{Conclusions}

Our study indicates that antibiotic producing bacteria in consortia isolated from a limestone cave could degrade the synthetic polymer polyethylene. Maximum biodegradation was observed when the medium was augmented with calcium salt, indicating higher degradation potential of bacterial consortia when in a medium close to the natural chemical composition of their native environment. Spectroscopy and microscopy results showed certain changes in low-density polyethylene test samples as compared to a control, indicating microbial breakdown of LDPE. Further research is needed to understand the mechanism of degradation of LDPE at a molecular level. All the bacterial strains were found to viable at the end of the experiment.

\section{ACKNOWLEDGEMENTS}

We are thankful to Quaid-i-Azam University, Islamabad, for providing funds to accomplish this research.

\section{REFERENCES}

Adetutu, E.M., and Ball, A.S., 2014, Microbial diversity and activity in caves: Microbiology Australia, v. 35, no. 4, p. 192-194. https://doi.org/10.1071/ MA14062.

Anwar, S., Liaquat, F., Khan, Q. M., Khalid, Z. M., and Iqbal, S., 2009, Biodegradation of chlorpyrifos and its hydrolysis product 3,5,6-trichloro2-pyridinol by Bacillus pumilus strain C2A1: Journal of Hazardous Materials, v. 168 , no. 1, p. 400-405. https://doi.org/10.1016/j.jhazmat. 2009.02.059. 
Bonhomme, S., Cuer, A., Delort, A.-M, Lemaire, J., Sancelme, M., and Scott, G., 2003, Environmental biodegradation of polyethylene: Polymer Degradation and Stability, v. 81 , no. 3, p. 441-452. https://doi.org/10. 1016/S0141-3910(03)00129-0.

Boonchan, S., Britz, M.L., and Stanley, G.A., 2000, Degradation and mineralization of high-molecular-weight polycyclic aromatic hydrocarbons by defined fungal-bacterial cocultures: Applied and Environmental Microbiology, v. 66, no. 3, p. 1007-1019.

Ciferri, O., 1999, Microbial degradation of paintings: Applied and Environmental Microbiology, v. 65, no. 3, p. 879-885.

Cruz, L.F., Cobine, P.A., and De La Fuente, L., 2012, Calcium increases Xylella fastidiosa surface attachment, biofilm formation, and twitching motility: Applied and Environmental Microbiology, v. 78, no. 5, p. 13211331. https://doi.org/10.1128/AEM.06501-11.

Cuezva, S., Fernandez-Cortes, A., Porca, E., Pašić, L., Jurado, V., HernandezMarine, M., Serrano-Ortiz, P., Hermosin, B., Cañaveras, J.C., SanchezMoral, S., and Saiz-Jimenez, C., 2012, The biogeochemical role of Actinobacteria in Altamira Cave, Spain: FEMS Microbiology Ecology, v. 81, no. 1, p. 281-290. https://doi.org/10.1111/j.1574-6941.2012.01391.x.

Cycoń, M., Wójcik, M., and Piotrowska-Seget, Z., 2011, Biodegradation kinetics of the benzimidazole fungicide thiophanate-methyl by bacteria isolated from loamy sand soil: Biodegradation, v. 22, no. 3, p. 573-583 https://doi.org/10.1007/s10532-010-9430-4.

De Leo, F., Iero, A., Zammit, G., and Urzì, C.E., 2012, Chemoorganotrophic bacteria isolated from biodeteriorated surfaces in cave and catacombs: International Journal of Speleology, v. 41, no. 2, p. 125-136. https://doi. org/10.5038/1827-806X.41.2.1.

Ehret, A E., and Böl, M., 2013, Modelling mechanical characteristics of microbial biofilms by network theory: Journal of The Royal Society Interface, v. 10, no. 78, p. 676-687. https://doi.org/10.1098/rsif.2012. 0676

Gu, Ji-Guang, and Gu, Ji-Dong., 2005, Methods currently used in testing microbiological degradation and deterioration of a wide range of polymeric materials with various degree of degradability: a review: Journal of Polymers and the Environment, v. 13, no. 1, p. 65-74. https:// doi.org/10.1007/s10924-004-1230-7.

Hadad, D., Geresh, S., and Sivan, A., 2005, Biodegradation of polyethylene by the thermophilic bacterium Brevibacillus borstelensis: Journal of Applied Microbiology, v. 98, no. 5, p. 1093-1100. https://doi.org/10.1111/j. 1365-2672.2005.02553.x.

Harshvardhan, K., and Jha, B., 2013, Biodegradation of low-density polyethylene by marine bacteria from pelagic waters, Arabian Sea, India: Marine Pollution Bulletin, v. 77, no. 1-2, p. 100-106. https://doi.org/10. 1016/j.marpolbul.2013.10.025.

Hasan, F., Shah, A.A., Hameed, A., and Ahmed, S., 2007, Synergistic effect of photo and chemical treatment on the rate of biodegradation of low density polyethylene by Fusarium sp. AF4: Journal of Applied Polymer Science, v. 105, no. 3, p. 1466-1470. https://doi.org/10.1002/app.26328.

Karlsson, S., and Albertsson, A.-C., 1998, Biodegradable polymers and environmental interaction: Polymer Engineering and Science, v. 38, no. 8, p. 1251-1253. https://doi.org/10.1002/pen.10294.

Kawai, F., 2010, The biochemistry and molecular biology of xenobiotic polymer degradation by microorganisms: Bioscience, Biotechnology, and Biochemistry, v. 74, no. 9, p. 1743-1759. https://doi.org/10.1271/bbb. 100394.

Kelly, S.D., Hesterberg, D., and Ravel, B., 2008, Analysis of soils and minerals using X-ray absorption spectroscopy, in Ulery, A.L., and Drees, L.R., eds., Mineralogical Methods: Madison, Wisconsin, Soil Science Society of America, Methods of Soil Analysis series 5, p. 387-463. https:// doi.org/10.2136/sssabookser5.5.c14.

Khan, M.N., 2013, The early arrival of Muslims in ancient Gandhāra study based on numismatic evidence from Kashmir Smast: Gandharan Studies, v. 7, p. 111-126

Lee, B., Pometto, A.L. III, Fratzke, A., and Bailey, T.B., Jr., 1991, Biodegradation of degradable plastic polyethylene by Phanerochaete and Streptomyces species: Applied and Environmental Microbiology, v. 57 , no. 3, p. 678-685.

Linos, A., Berekaa, M.M., Reichelt, R., Keller, U., Schmitt, J., Flemming, H.C., Kroppenstedt, R.M., and Steinbüchel, A., 2000, Biodegradation of cis1,4-polyisoprene rubbers by distinct actinomycetes: microbial strategies and detailed surface analysis: Applied and Environmental Microbiology, v. 66 , no. 4, p. 1639-1645. https://doi.org/10.1128/AEM.66.4.1639-1645. 2000 .

Margesin, R., Schumann, P., Spröer, C., and Gounot, A.-M., 2004, Arthrobacter psychrophenolicus sp. nov., isolated from an alpine ice cave: International Journal of Systematic and Evolutionary Microbiology, v. 54, no. 6, p. 2067-2072. https://doi.org/10.1099/ijs.0.63124-0.

Matsunaga, M., and Whitney, P.J., 2000, Surface changes brought about by corona discharge treatment of polyethylene film and the effect on subsequent microbial colonisation: Polymer Degradation and Stability, v. 70, no. 3, p. 325-332. https://doi.org/10.1016/S0141-3910(00)00105-1.

Nkwachukwu, O.I., Chima, C.H., Ikenna, A.O., and Albert, L., 2013, Focus on potential environmental issues on plastic world towards a sustainable plastic recycling in developing countries: International Journal of Industrial Chemistry, v. 4, no. 1, p. 34 46. https://doi.org/10.1186/ 2228-5547-4-34

Orhan, Y., and Büyükgüngör, H., 2000, Enhancement of biodegradability of disposable polyethylene in controlled biological soil: International Biodeterioration \& Biodegradation, v. 45, no. 1-2, p. 49-55. https://doi org/10.1016/S0964-8305(00)00048-2.

Rajandas, H., Parimannan, S., Sathasivam, K., Ravichandran, M., and Yin, Li Su, 2012, A novel FTIR-ATR spectroscopy based technique for the estimation of low-density polyethylene biodegradation: Polymer Testing, v. 31, no. 8, p. 1094-1099. https://doi.org/10.1016/j.polymertesting.2012. 07.015 .

Rivard, C., Moens, L., Roberts, K., Brigham, J., and Kelley, S., 1995, Starch esters as biodegradable plastics: effects of ester group chain length and degree of substitution on anaerobic biodegradation: Enzyme and Microbial Technology, v. 17, no. 9, p. 848-852. https://doi.org/10.1016/ 0141-0229(94)00120-G.

Schabereiter-Gurtner, C., Saiz-Jimenez, C., Piñar, G., Lubitz, W., and Rölleke, S., 2002, Altamira cave Paleolithic paintings harbor partly unknown bacterial communities: FEMS Microbiology Letters, v. 211, no. 1, p. 7-11. https://doi.org/10.1111/j.1574-6968.2002.tb11195.x.

Shah, A.A., Nawaz, A., Kanwal, L., Hasan, F., Khan, S., and Badshah, M., 2015, Degradation of poly ( $\varepsilon$-caprolactone) by a thermophilic bacterium Ralstonia sp. strain MRL-TL isolated from hot spring: International Biodeterioration \& Biodegradation, v. 98, p. 35-42. https://doi.org/10. 1016/j.ibiod.2014.11.017.

Sharma, A., and Sharma, A., 2004, Degradation assessment of low density polythene (LDP) and polythene (PP) by an indigenous isolate of Pseudomonas stutzeri: Journal of Scientific and Industrial Research, v. 63 , no. 3, p. 293-296.

Shimao, M., 2001, Biodegradation of plastics: Current Opinion in Biotechnology, v. 12, no. 3, p. 242-247. https://doi.org/10.1016/ S0958-1669(00)00206-8.

Tribedi, P., and Sil, A.K., 2013, Low-density polyethylene degradation by Pseudomonas sp. AKS2 biofilm: Environmental Science and Pollution Research, v. 20, no. 6, p. 4146-4153. https://doi.org/10.1007/ s11356-012-1378-y.

Webb, H.K., Arnott, J., Crawford, R.J., and Ivanova, E.P., 2012, Plastic degradation and its environmental implications with special reference to poly(ethylene terephthalate): Polymers, v. 5, no. 1, p. 1-18. https://doi.org/ 10.3390/polym5010001.

Zada, S., Nasem, A.A., Lee, Seong-Joo., Rafiq, M., Khan, I., Shah, A.A., and Hasan, F., 2016, Geochemical and mineralogical analysis of Kashmir Cave (SMAST), Buner, Pakistan, and isolation and characterization of bacteria having antibacterial activity: Journal of Cave and Karst Studies, v. 78, no. 2, p. 94-109. https://doi.org/10.4311/2014MB0110. 